was interrupted by the Nazi seizure of power and Krebs leaving that country; with Verzar in Basel, and then with Krebs again, in Cambridge. In Lwow he participated in the team work, with myself and Dr. T. Mann, now in Cambridge, which led to the discovery of direct enzymatic transfer of the phosphate group from phosphoglyceric to adenylic acid, with the formation of adenosintriphosphoric acid, and to the chart of the linkage of chemical transformation in glycogenolysis, as now generally accepted. With T. Baranowski and J. Reis (now in the British Eighth Army), Ostern discovered (1935) the direct transfer of phosphate from adenosintriphosphoric acid to creatine, and the role of the phosphocreatine-creatine system as an alternating acceptor and donor of phosphate was disclosed; in 1936 he discovered that Harden-Young fructosediphosphate is formed from the monoesters and adenosintriphosphoric acid, and this very important link in glycogenolysis and glycolysis, the inhibition of which by oxidizing agents, as recently found by Engelhardt, is the essential factor of the Pasteur effect, was discovered by Ostern and his associates. His last important discovery was made, with $\mathrm{E}$. Holmes and D. Herbert, in 1939, during a short stay in Cambridge-that glucose is formed in the liver by way of phosphorolysis of glycogen and subsequent hydrolysis of the phosphoric ester. The formation of glycogen from the Cori ester by liver enzymes was then published by these workers, simultaneously with the St. Louis group.

In 1940 Ostern was appointed professor of organic chemistry in the Medical School in Lwow. Unfortunately, he did not leave the city when the Germans approached. His many friends abroad will deeply regret the untimely death of this outstanding scientific worker.

J. K. Parnas.

\section{Prof. Forsyth James Wilson}

Prof. F. J. Wirson, Freeland professor of chemistry in the Royal Technical College, Glasgow, died suddenly on October 18. For the long period of thirty-eight years he had been associated with the College which he served faithfully and well ; his first appointment was that of chief assistant to Prof. G. G. Henderson. During the period 1914-19 he served in the Army, ultimately as chemical adviser to the Eleventh Army Corps. On more than one occasion he was mentioned in dispatches.

In 1919 Wilson returned to the College to fill the chair of inorganic and analytical chemistry. On the transfer of Prof. I. M. Heilbron to the University of Liverpool, he succeeded, at his own request, to the ohair of organic chemistry, and held that until the death of Prof. R. M. Caven, when the two chairs were amalgamated in the Freeland Chair. This is good evidence of his breadth of knowledge of the subject.

Born at Moffat in 1880, Dr. Wilson received his earlier training at the University of Edinburgh, from which he passed after a distinguished record to Leipzig, being associated there with Hantsch and Stobbe. On returning to Great Britain he joined Prof. A. G. Green at Leeds in research on dyestuffs.

In Glasgow, he took a lively interest in all the local sections of the various chemical societies and at different intervals acted as chairman. He was meticulous in his attendance at meetings, and his general bearing in discussion was always courteous. In due course he served on the councils of the
Chemical Society and the Royal Institute of Chemistry, and held office for more than one period in each case. Nearest to his heart was perhaps the British Association, and he rarely missed a meeting of the Chemistry Section.

In the limited time available from heavy official and teaching duties, Wilson was actively engaged on research in organic chemistry, collaborating with many colleagues, among them Stobbe, Boon, Heilbron, and more recently with members of the present staff of the College, Sutherland, Hopper, Crawford, McLean, and others. His research work was mainly devoted to a study of stereoisomerism with special reference to derivatives of semicarbazide and thiosemicarbazide, and to the resolution of optically active compounds derived therefrom. Latterly, he developed a special interest in certain aspects of chemotherapy, and in this connexion was associated with Imperial Chemical Industries Ltd. He was a frequent contributor to the Journal of the Chemical Society. With Prof. Heilbron he published a very useful little book on "Chemical Theory and Calculations"; although now out of print, it earned welldeserved popularity among a wide circle of students some twenty years ago.

Wilson's work in and for the Royal Technical College, Glasgow, met with unqualified approval and success, and his influence upon his students as well as his personal relations with them were admirable. Many of them holding important positions throughout the world will recall with pleasure his warm personal interest in their well-being, both during and after college days. Of shy and retiring disposition, he was a man of considerable grace and charm, highly respected and esteemed by his colleagues, no less than by his students. $\quad$ W. M. Commarng.

\section{Dr. Henry J. S. Sand}

DR. HENRY J. S. SAND died, after a short illness, at Nottingham on October 18. He will be remembered as an electrochemist of international repute, and he had also published outstanding original work in other branches of chemistry.

Dr. Sand was born in Dundee on December 7, 1873. He received his early education at the High School, Dundee, and later at the Realgymnasium in Dresden. It was during these early years in Germany that the foundations were laid of his excellent knowledge of the German language. For a short time he studied under Hempel at the Dresden Polytechnic, and then continued his university career at Zurich, where his inaugural dissertation was published in 1898. Here he worked under Bamberger, studying organic chemistry, and was awarded the degree of Ph.D. Upon his return to England, Dr. Sand worked with Ramsay at University College, London, for a short period and then, as a holder of a Bowen Research Scholarship at the University of Birmingham during 1899-1901, commenced the studies in electrochemistry for which he is so well known.

In 1901 Dr. Sand took up the post of lecturer and demonstrator under Prof. Kipping at University College, Nottingham, and continued his researches. He was awarded the degree of D.Sc. at Birmingham in 1905. In 1914 he moved to London and held the post of senior lecturer in chemistry at the Sir John Cass Technical Institute, London, until 1921, after which date until he retired in 1938 he was head of the Department of Inorganic and Physical Chemistry. 
Sand's published scientific work is contained in about fifty original papers with subjects varying in scope from laboratory apparatus of his own design and construction to theoretical discussions in thermodynamics. He was thus both an able and skilled experimenter and a thinker of wide scientific outlook. Outstanding among his original investigations are the work on electrode processes including diffusion at electrodes and over-voltage, the development of vacuum-tight seals for leading in wires to silica and glass vessels, and various improved methods of electrochemical analysis. Particularly among these should be mentioned the separation of metals by control of electrode potential and the use of 'internal' electrolysis for determination of metallic elements in the presence of larger quantities of less noble metals. In 1939,1940 and 1941 there were published successively the three volumes of his "Electrochemistry and Electrochemical Analysis", a work upon which he had spent many years of thought and labour and which summarized the state of electrochemical knowledge to that date.
To those who had the privilege of knowing him, Dr. Sand was a most amiable man. His former colleagues and research students particularly will remember his tolerant and kindly criticism, his balanced judgment and his unfailing help, which he gave freely to all those who brought their problems before him. He will be remembered and missed by many friends all over the world, and they will think with sympathy of his widow, and his only son who is now serving with the British Army overseas.

ARthuR J. LINDSEY:

WE regret to announce the following deaths :

Sir Joseph Arkwright, F.R.S., honorary bacteriologist at the Lister Institute, on November 22, aged eighty years.

Prof. Charles F. Park, emeritus professor of mechanical engineering at the Massachusetts Institute of Technology, director of the Lowell Institute School, on September 25, aged seventy-five years.

\section{NEWS and VIEWS}

\section{The Times and Freedom of the Press}

How often do readers notice the serial number at the front of a journal? Yet this number is much more than a convenient means of identification used by publishers and printers; as is pointed out in an article in The Times of November 25, it indicates the intention of continuing to produce the journal at short intervals, so that the reader can follow the progress of events--it is a sign of continuous and watchful activity. The Times has given this service to Great Britain for the past century and a half, and it has now proudly inscribed the number 50,000 on the front page of its issue of November 25. As the years have gone by, The Times has grown in stature, under a succession of distinguished editors, until it is now an organ of international repute.

The leading article of the 50,000th issue rightly ends on the note of the freedom of the Press. One of the first acts of an authoritarian regime is to suppress the expression of contrary views; government by consent of the people, the very essence of democracy, requires a free Press, able to reflect and to guide public opinion. In times of war, a democracy must accept, however grudgingly, a considerable measure of dictation, including censorship of the Press. This suppression of facts in the interests of national security is an evil necessity under which every member of a democracy must chafe; particularly is this restriction of publication felt in scientific circles, where the free interchange of news and views is the life-blood of progress. The Times, with other journals, has accepted the necessity of censorship, but it declares in no uncertain terms its policy for the future: "As the war draws to an end and the shadow of military necessity recedes, the immediate task will be to ensure that every encroachment of authority shall be rolled back from a field of responsibility in which, in a free community, it can have no place". It will bave the support of all who value democracy in carrying out this policy in the years to come.

\section{Communities and Industry}

THE broadsheet "Location of Employment" issued by Political and Economic Planning is a timely contribution to the discussion of the fundamental questions in town and country planning on which early decisions must now be taken by the Government. The broadsheet attempts first to analyse the employment needs which are relevant to physical planning, and then considers how far those needs could be met on the scale of a community comprising not more than about 60,000 people. The conclusion is reached that a satisfactory variety of industry and occupation can usually only be provided for a group of communities, and not, as town-planners have often suggested, for each community separately. The important concept is not so much that of the community as that of the employment orbit, or the area in which any point can be reached within reasonable daily travelling time by the members of the community. For some communities it may be far better to improve communications with other places than to try to bring industry within the borders of the community. It should be possible for the majority of wage-earners to find work fairly near to their homes; many jobs in secondary and tertiary industries can be located in the community itself, and the broadsheet points out that the employment exchanges, by the use of judicious and flexible placing methods, can help in this. Secondly, the time taken up in travelling to work can be cut down by improving transport and by careful layout and correlation of the several communities.

Even when communities have been grouped in this way for purposes of employment, there may still be some which have no economic future by themselves and are so isolated that they cannot be combined in a larger region. Such communities, Planning considers, should be closed down. Again, the employment orbits suggested may not be suitable units for the industrialist. The advantages he requires may not always be provided therein; but it should be 